\title{
EFFECT OF THE SOWING SPEED AND DEPTH ON SOME ECONOMICAL, TECHNICALINDICATORS AND ENERGY REQUIREMENTS FOR MACHINERY UNIT
}

\author{
Kasim Mosa Madlol *
}

\begin{abstract}
The experiment was conducted in fields of Agricultural College University of Baghdad in 2009 insilt - clayey soil in order to study the effect of sowing speeds on some economical, technical performance indicators and energy requirements for machinery unit under variable levels of sowing depths. The tractor "New Holland" and the grain drill "Stegested"were used machineryunit. Threesowingspeed $6.28,7.61$, and 11.43) km / hrepresented the main plots and three sowing depths (3, 6, and 9) cm represented the sub-plots. Some technical performance indicators for machinery unit were studiedwhich include: percentage of slippage, effective field capacity, field efficiency and fuel consumption per unit area, as well as calculating the total operation costs and energy requirements for the machinery unit. The Experiment was carried out by using split - plot with complete randomized block design in three replicates. The results showed that the third speed of sowing $11.43 \mathrm{~km} / \mathrm{h}$ was superior among other sowing speeds in recording higher rate of effective field capacity of 1.08ha / $h$ and lower rate of fuel consumption per unit area of $8.11 \mathrm{~L} / \mathrm{ha}$ and lower rate of total operation costs for machinery unitof 13594 ID / ha(10.875 US\$ / ha) with lower rate of energy requirements for machinery unit of $29.40 \mathrm{~kW}$. $h$ / ha while the percentage of slip was within the permissible limits of 10.98\%.The first depth of sowing of $3 \mathrm{~cm}$ was superior amongother sowing depths in recording lower rate of slippage percentage of $4.64 \%$ and higher rate of effective field capacity $(0.87 \mathrm{ha} / \mathrm{h})$ and higher rate of field efficiency $(71.72 \%)$ with lower rate of fuel consumption per unit area of $8.38 \mathrm{~L} / \mathrm{ha}$ and lower rate of total operation costs for machinery unit of 16721 ID / ha (13.376 US\$ / ha) with lower rate of energy requirements for machinery unit of $30.34 \mathrm{~kW}$. $\mathrm{h} / \mathrm{ha}$.
\end{abstract}

* Assist. Lect., Dept. Of Agric. Mach. And Equip., Col. Agric., Univ. of Baghdad 
As for the interaction between sowingspeedand sowing depth, it was significant for all parameters whereas the third speed of sowing of 11.43 $\mathrm{km} / \mathrm{h}$ with the first depth of sowing $(3 \mathrm{~cm})$ was superior in recording higher rate of effective field capacity $(1.16 \mathrm{ha} / \mathrm{h})$ and lower rate of fuel consumption per unit area $(6.32 \mathrm{~L} / \mathrm{ha})$ and lower rate of total operation costs for machineryunit of 12022 ID / ha (9.617 US\$ / ha) with lower rate of energy requirements for machinery unit $(23.05 \mathrm{~kW} . \mathrm{h} / \mathrm{ha})$ while the percentage of slip was within the permissible limits of $6.59 \%$.

\section{INTRODUCTION}

$\mathrm{N}$ ourishing the rapidly growing world population calls for a rapid increase in food by increasing agricultural production. An increase in agricultural production is not only of interest from the point of view of nourishment of the world population, but is also the central problem of the whole national economic development in the majority of emergent countries. The efforts towards a rapid extension of agricultural production, especially cereal production, by increasing the areas of cereal crop and the development of cereal production(Glanze 1972).New lands in agriculture do not fill the large and growing need for food,because of decreasingthrough the expansion of cities, roads, picnic areas,therefore, care must be taken to develop agricultural production in currently used land by mechanization of agricultural operations and usingthe moderntechniques in agriculture (Ahmed and Munther, 1987).Mechanical sowing is an important process whichis done after tillage and harrowing,that it is providing a saving in the time and labor, accuracy of the required work, lowering of wasted seeds and ease of crop service operations in comparison with hand sowing as well as exposing the worker in the hand sowing to toxins as a result of inhalation of air or touch by handbecause of dusting seeds, in addition losing amount of seeds by birds and ants (Abdulrahman, 1992 and Awadyet al.2006). The use of imported grain drills can reduce a big rate in the lost grain as it can increase crop yields if used in land which iswell prepared in terms of deeper plowing, leveling and harrowing required in the region (Al-Rajabow, 2002).In view of the short time periodfor sowing, it is necessary to resort to the optimal use of grain drills and the maximum 
capacity by increasing the sowing speed to the maximum extent possible within the permissible limits of the slip, taking into consideration the capacity of available tractor and the grain drill efficiency for accurate work at high speeds (Abu Sabaa and Karim, 1980). Mohammed (2005)found that increase of the speed of the sowing from 3.51 to 6.21 then to $8.76 \mathrm{~km} / \mathrm{h}$ led to a significant increase in the percentage of slippage from 6.23 to 9.44 and then to $11.48 \%$.Al-Mkhiol (2005) has noted that the percentage of slippage had increased from 3.24 to 4.13 then to $4.89 \%$ when speed of sowing had increased from 4.39 to 6.42 then to $8.81 \mathrm{~km} / \mathrm{h}$ and the two were because increasing of practical speed leads to increase traction force required to pull the grain drill.Therefore, slippage will increase.Al-Khafaji (2006) showed that there are apparent increases in the effective field capacity of grain drill in two ratios of increase from 40 to $120 \%$ when increasing speed of sowing from 5 to $11 \mathrm{~km} / \mathrm{h}$ and then decrease the required time to complete agricultural process.Madlol (2010) found that the speed has a significant effect in the equipment field efficiency where it was lowered from 68.22 to 67.25 then to $65.81 \%$ when the practical speed increased from 3.27 to 5.00 then to $6.72 \mathrm{~km} / \mathrm{h}$, indicating that the reason is reducing of time exploitation coefficient.Kassar (2011) Noted significant effect of sowing speed in fuel consumption values where by increasing of sowing speed from 6.8 to 9.26 and then to $11.17 \mathrm{~km} / \mathrm{h}$ the values of fuel consumption decreased from 7.164 to 5.972 then to $5.360 \mathrm{~L} /$ ha.Also Al-Khafaji (2006) found a significant decrease in fuel requirements per unit area when increasing the practical speed of sowingas well.Aday et al. (2008) concluded that higher tractor forward speed may have given the least amount of fuel consumed per unit area and all of them had showed that the reason is that the high speed leads to a short in period of time to complete the unit area as well as losing the tractor ability optimally in the slow speeds. Al-Sharefy (2003)noted that there is a decrease in the rates of total operation costs of machinery unit in two ratios of decrease from 75 to $47 \%$, during increasing of practical speed rate from 2.052 to 4.643 then to $5.459 \mathrm{~km} / \mathrm{h}$ due to increasing of practical speed and increase of practical productivity, therefore the total costs decreased as a result of the reverse relationship between the two. Increase of speed is at the expense 
of specification which should be achieved in the operation of sowing because of rolling seeds and vibrating depth and poor penetration of furrow opener for soil (Abu Sabaa and Karim, 1980). The decline in production of grain crops, due to lack of using the crop management of appropriate sowing depth which affects clearly germination and emergence and fieldestablishment, which is the outcome of germination ,administration and the environment (Anderson and Garling, 2000). The sowing depth is an important factor in crop's management affecting productivity. Itdepends on the soil type, moisture degree, the seed size, irrigation system and class of crop (Al-Izzi, 2004). Accordingly, the sowing depth is the basis to ensure the homogeneity, faster germination and the establishment for good emergence (Jadou and Haider, 2012).Al-Sulaivany(2005)found that increasing the sowing depth from 3 to 5 and then to $7 \mathrm{~cm}$ led to increased slippage from 7.85 to 8.08 and then to $10.29 \%$.She attributed the traction force increases to increasing the depth and slippage.Jasim and Madlol (2011)noted that the equipment practical productivity has decreased from 0.649 to 0.617 then to 0.569 ha / $\mathrm{h}$ when the depth increased from 5 to 10 then to $15 \mathrm{~cm}$. He attributed the reason that increasing depth will lead to increased slip and thus lees, practical speed so the practical productivity will decreasetoo.Zedan (2006) and Madlol and Abdulrazzak (2012)concluded that less depth gave the highest field efficiency and explained the increasing depth accompanied by a decrease in practical speed, thus practical productivity will decrease, therefore field efficiency too.Desbilles (2005) showed that the planting depth has largest impact on the traction force requirements, which effects increasing fuel consumption per unit area.Al-Aridhee (2011) found that fuel consumption may fit directly proportional with increasing depth, and attributed that to the increased depth requiring, more work and more fuel consumption.Al-Janobi (2000) noted that the total cost for machinery unit increased by increasing depth,as well.Jabour (2010) concluded that increasing depth from 13 to $21 \mathrm{~cm}$ led to an increase in the total costs and the reason is decreasing the practical productivity, thereby increasing the total costs. Al- Sabbaghet al. (2012) found that increasing the operation depth from 10 to $20 \mathrm{~cm}$ led to an increase in machinery unit energy requirements from 158.596 to 214.624 
$\mathrm{kW} . \mathrm{h} / \mathrm{ha}$.Increasing the depth was accompanied by an increase in fuel consumption as a result of increasing the slippage thereby increasing of energy requirements for the machinery unit. Using different types of grain drills in different ground speeds of sowing and numerous sowing depths is one of the indirect causes that lead to a reduction of germination ratio and thus the lack in production and low profits compared to the cost of production.Therefore many farmers use spinning disc bulk chemical fertilizer distributor (Centrifugal Broadcasters)in the sowing operation for its numerous advantages without taking into account the economic losses caused by increasing the amount of seed out of the allowable rate.For that,it helps to indicate the best combination between the sowing speed and depth that gives the best technical, economic indicators and energy requirements of the machinery unit (tractor + grain drill) in this study.

\section{MATERIALS AND METHODS}

The field experiment was carried out in one of the fields of the Agricultural College - Baghdad University in 2009.Field soil classified as a sedimentary - silt clay loam, whose physical and chemical characteristics are shown in Table (1).

Table (1): Some chemical and physical characteristics for the studied field soil

\begin{tabular}{|c|c|c|c|c|c|c|c|c|}
\hline \multicolumn{3}{|c|}{$\begin{array}{l}\text { Particle-Size } \\
\text { Distribution }\end{array}$} & \multirow[t]{2}{*}{$\begin{array}{l}\text { Soil } \\
\text { class }\end{array}$} & \multirow{2}{*}{$\begin{array}{c}\text { Bulk } \\
\text { density } \\
\left(\mathrm{g} / \mathrm{cm}^{3}\right)\end{array}$} & \multirow{2}{*}{$\begin{array}{c}\text { Total } \\
\text { porosity } \\
\text { (\%) }\end{array}$} & \multirow{2}{*}{$\begin{array}{c}\text { Soil-moisture } \\
\text { Content } \\
\text { (\%) }\end{array}$} & \multirow{2}{*}{$\begin{array}{c}\text { Electrical } \\
\text { conductivity } \\
\text { (EC) } \\
\text { mmhos/cm. }\end{array}$} & \multirow[t]{2}{*}{$\begin{array}{l}\text { Soil } \\
(\mathrm{pH})\end{array}$} \\
\hline $\begin{array}{c}\text { Sand } \\
\%\end{array}$ & $\begin{array}{c}\text { Silt } \\
\%\end{array}$ & $\begin{array}{c}\text { clay } \\
\%\end{array}$ & & & & & & \\
\hline 40 & 530 & 430 & SI -CL & 1.54 & 42.08 & 16.75 & 12.5 & 7.6 \\
\hline
\end{tabular}

The tractor used was "New Holland" brand name (80-66S), Italian-made, two - wheel drive, model 2000 at a nominal power of $80 \mathrm{hp}(60 \mathrm{~kW})$ under $2000 \mathrm{rpm}$ forengine. Grain drill brand name "Stegsted", Danishmade, r-point linkage mounted. Design width $170 \mathrm{~cm}$ (the number of furrow opener 17 and the spacing between furrow openers $10 \mathrm{~cm}$ ), double disc - type,placed on a frame has ability to rise and fall by an arm in order to control depth after placing wooden blocks under grain drill 
tires.Studded roller- feeding mechanism which rotates just below the seed box and draws seed from the bottom of the box into hoppers at the tops of the seed tubes. The feeding mechanism received movement from ground wheel of grain drill. Capacity of grain drill hopper $r 00 \mathrm{~kg}$, where Put in it seeds of wheat under class "Abu Gharib" Two factors were studied in this researchaffectingtechnical performance indicators, total operating costs and energy requirements of the machinery unit, (1)the sowing speed was selected as $(6.28,7.61,11.43) \mathrm{km} / \mathrm{h}$ respectively which represented the main plots,and (2) the sowing depth with three levels $(3,6,9) \mathrm{cm}$ respectively which represented the sub-plots. The experiment was conducted after plowing the field by sweep plow and harrowing by spring - tooth cultivator - harrow, and then the field was segmented within experimental design.The experiment was designed according to (Split -Plot - Design) under (Randomized Complete Block Design) with three replicates.So the number of experimental units (replicates) was $27(3 \times 3 \times 3)$. Thedata were collected and analyzed according to experimental design and differences between treatments weretested by Least Squares Differences(LSD) at probability level 5\% (Al-Rawi and Abdulaziz, 1980). Then the following indicatorswere studied as follows: -

\section{- The slippage (\%)}

The slippage percentage was calculated by using the following equation:

- (Awady, 1987) and (Al-Janobi and Zeineldin, 1997)

$\mathrm{SP}=\left[\left(\mathrm{V}_{\mathrm{T}}-\mathrm{V}_{\mathrm{P}}\right) / \mathrm{V}_{\mathrm{T}}\right] \times 100$-------------------\%

Where:

$\mathrm{SP}=$ slippage percentage $(\%) ; \mathrm{V}_{\mathrm{T}}=$ theoretical speed $(\mathrm{km} / \mathrm{h}) ; \mathrm{V}_{\mathrm{P}}=$ practical speed $(\mathrm{km} / \mathrm{h})$.

\section{- Effective field capacity (practical productivity) (ha / h)}

The effective field capacity was calculated by using the following equation: - (Elmo, 1981) and(Kepner et al. 1982) and (Awady, 2002)

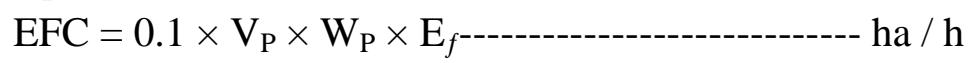
Where:

$\mathrm{EFC}=$ effective field capacity $(\mathrm{ha} / \mathrm{h}) ; \mathrm{W}_{\mathrm{P}}=$ rated width of grain drill 
(m); $\mathrm{E}_{f}=$ field efficiency, in percent, assumed to be $70 \%$ for the grain drill equipment (Kepner et al. 1982).

\section{- Field efficiency (\%)}

The Field efficiency was calculated by using the following equation: (Hanna, 2002)

$\mathrm{FE}=\mathrm{EFC} / \mathrm{TFC} \times 100$ $\%$

Where:

$\mathrm{FE}=$ field efficiency $(\%) ; \mathrm{TFC}=$ theoretical field capacity $(\mathrm{ha} / \mathrm{h})$.

\section{- Fuel consumption ( $\mathrm{L} / \mathrm{ha})$}

The fuel consumption for the traveled distance in the treatment (30) $\mathrm{m}$ was measured by using a glass cylinder tool $1000 \mathrm{ml}$ - capacity, then the fuel consumption per unit area (ha) was calculated by using the following equation: - (Khalilian et al. 1988)

Fu.C $=\mathrm{Qd} \times 10000 / \mathrm{W}_{\mathrm{P}} \times \mathrm{D} \times 1000=10 \mathrm{Qd} / \mathrm{W}_{\mathrm{P}} \times \mathrm{D}$------------ $\mathrm{L} /$ ha

Where:

Fu.C = fuel consumption per unit area ( $\mathrm{L} / \mathrm{ha}) ; \mathrm{Qd}=$ fuel consumed during the treatment $(\mathrm{ml}) ; \mathrm{D}=$ traveled distance during thetreatment $(\mathrm{m})$.

\section{- Total operation costs (ID / ha)}

The total operation costs of the machinery unit (tractor + grain drill) wascalculated according to ASAE (2000), which included:-fixed costs including (depreciation, interest on investment, taxes, insurance and shelter), Variable costs include (fuel, oils, maintenance, repairs and labours), Administrative costs and tractor's total cost.As for grain drill, the same preceding items were applied to calculate the operating costs, except variable costs which werecalculated by multiplying the fixed costs value of grain drill times $80 \%$ because it do not have a power source (engine) (Al-Tahan et al. 1991). Declining - Balance Depreciation was the method adopted to calculate the depreciation for the tractor and grain drill (Hunt, 2001) and (Issct, 2004). 


\section{-Energy requirements $(\mathrm{kW} . \mathrm{h} / \mathrm{ha})$}

Engine power was calculated by using the following equation: (Embaby, 1985)

$\mathrm{EP}=3.16 \mathrm{FC}$ $\mathrm{kW}$

Where:

$\mathrm{EP}=$ engine power $(\mathrm{kW}) ; \mathrm{FC}=$ fuel consumption $(\mathrm{L} / \mathrm{h})$

Then theenergy requirement of the machinery unit was calculated by using the following equation: - (Embaby, 1985)

$\mathrm{ER}=\mathrm{EP} / \mathrm{EFC}$ $\mathrm{kW} . \mathrm{h} / \mathrm{ha}$

Where:

$\mathrm{ER}=$ energy requirements $(\mathrm{kW} . \mathrm{h} / \mathrm{ha}) ; \mathrm{EFC}=$ effective field capacity (ha / h).

\section{RESULTS AND DISCUSSION}

\section{- The percentage of slippage}

Table (2):Effect of the sowing speed and depth on the percentage of slippage $(\%)$

\begin{tabular}{|c|c|c|c|c|}
\hline \multirow{2}{*}{$\begin{array}{c}\text { The sowing speed } \\
(\mathrm{km} / \mathrm{h})\end{array}$} & \multicolumn{3}{|c|}{ The sowing depth(cm) } & $\begin{array}{c}\text { Average } \\
\text { sowing speed }\end{array}$ \\
\cline { 2 - 4 } & 3 & 6 & 9 & 7.77 \\
\hline 6.28 & 2.57 & 9.06 & 11.67 & 9.53 \\
\hline 7.61 & 4.76 & 10.82 & 13.02 & 10.98 \\
\hline 11.43 & 6.59 & 12.11 & 14.23 & 1.08 \\
\hline L.S.D =0.05 & \multicolumn{3}{|l}{2.04} & \\
\hline $\begin{array}{c}\text { Average sowing } \\
\text { depth }\end{array}$ & 4.64 & 10.66 & 12.97 & \\
\hline L.S.D =0.05 & \multicolumn{3}{|l}{1.08} & \\
\hline
\end{tabular}

Table (2) shows the effect of sowing speed and sowing depth and their overlaps on the percentage of slippage. As seen from the table, increasing the sowing speed from 6.28 to 7.61 and then to $11.43 \mathrm{~km} / \mathrm{h}$ led to increase the slippage percentage from $7.77 \%$ to $9.53 \%$ and then to $10.98 \%$, respectively. This may be due to the increased practical speed leading to increase traction resistance force and reduce the chance of the 
driving wheel coherence of the tractor with the ground, therefore the slip increased. These results are consistent with the ones obtained by Mohammed (2005) and Al-Mkhiol (2005).Also the results in the same table show that increasing the sowing depth from 3 to 6 and then to $9 \mathrm{~cm}$ caused an increase in the percentage of slipping from $4.64 \%$ to $10.66 \%$ and to $12.97 \%$, respectively, The reason is that the increase of depth has led to increased loading on the furrow openers and it's penetrate in the ground, which cause an increase in the traction resistance force therefore the slip increases. These results are consistent with those obtained by AlSulaivany (2005). The interaction between the sowing speed and the sowing depth was significant on the percentage of slip, whereas the dual overlap between the sowing speed $6.28 \mathrm{~km} / \mathrm{h}$ and the sowing depth $3 \mathrm{cmledto}$ obtain the lowest percentage of slip was $2.57 \%$, while the highest percentage of slip was $14.23 \%$ resulting from the overlap of the sowing speed $11.43 \mathrm{~km} /$ hwith the sowing depth $9 \mathrm{~cm}$.

\section{- Effective field capacity (practical productivity)}

The effect of the sowing speed and the sowing depth and their overlaps on the effective field capacity is givers in table (3). As seen from the table,the increaseof the sowing speed from 6.28 to 7.61 and then to $11.43 \mathrm{~km} /$ hincreasedeffective field capacity from 0.61 to 0.73 then to 1.08 ha / h,respectively. The reason may be attributed to the fact that speed is one of the factors involved in the calculation of productivity. These results are consistent with theresultsobtained by Al-Khafaji (2006). The same table shows that increasing the sowing depth from 3 to $6 \mathrm{~cm}$ the practical productivity has decreased from 0.87 to $0.78 \mathrm{ha} / \mathrm{h}$. The reason is that increasing depth will be followed by increasing penetration of the furrow openers in the soilleading to increase the traction resistance force and thus, practical speed will decrease, which is one of the factors of practical productivity. These results are consistent with those obtained byJasim and Madlol(2011) and Abu Sabaa and Karim (1980), while increasing the sowing depth from 6 to $9 \mathrm{~cm}$ did not have any significant effect in the practical productivity.The interaction between the sowing speed and the sowing depth was significantin the practical productivity.Interaction of the sowing speed $11.43 \mathrm{~km} /$ hwiththe sowing 
depth $3 \mathrm{~cm}$ was superior in obtaining highest value of productivity rate amounting to $1.16 \mathrm{ha} / \mathrm{h}$. whilethe lowestfieldcapacity rate was $0.58 \mathrm{ha} / \mathrm{h}$ which was resulting from overlap of the sowing speed $6.28 \mathrm{~km} / \mathrm{hwith}$ the sowing depth9cm.

Table (3):Effect of the sowing speed and depth on the effective field capacity (ha / h)

\begin{tabular}{|c|c|c|c|c|}
\hline \multirow{2}{*}{$\begin{array}{c}\text { The sowing speed } \\
(\mathrm{km} / \mathrm{h})\end{array}$} & \multicolumn{3}{|c|}{ The sowing depth $(\mathrm{cm})$} & $\begin{array}{c}\text { Average } \\
\text { sowing speed }\end{array}$ \\
\cline { 2 - 4 } & 3 & 6 & 9 & 0.61 \\
\hline 6.28 & 0.67 & 0.58 & 0.58 & 0.73 \\
\hline 7.61 & 0.76 & 0.71 & 0.71 & 1.08 \\
\hline 11.43 & 1.16 & 1.05 & 1.03 & 0.02 \\
\hline L.S.D $=0.05$ & \multicolumn{3}{|c}{0.04} & \\
\hline Average sowing depth & 0.87 & 0.78 & 0.77 & \\
\hline L.S.D $=0.05$ & \multicolumn{3}{|c}{0.02} & \\
\hline
\end{tabular}

\section{- Field efficiency}

Table (4):Effect of the sowing speed and depth on the field efficiency $(\%)$

\begin{tabular}{|c|c|c|c|c|}
\hline \multirow{2}{*}{$\begin{array}{c}\text { The sowing speed } \\
(\mathrm{km} / \mathrm{h})\end{array}$} & \multicolumn{3}{|c|}{ The sowing depth $(\mathrm{cm})$} & \multirow{2}{*}{$\begin{array}{c}\text { Average } \\
\text { sowing speed }\end{array}$} \\
\cline { 2 - 4 } & 3 & 6 & 9 & 68.60 \\
\hline 6.28 & 75.66 & 65.17 & 64.98 & 66.82 \\
\hline 7.61 & 70.03 & 65.29 & 65.14 & 64.71 \\
\hline 11.43 & 69.46 & 62.98 & 61.68 & 1.47 \\
\hline L.S.D =0.05 & \multicolumn{3}{|c|}{2.96} & \\
\hline $\begin{array}{c}\text { Average sowing } \\
\text { depth }\end{array}$ & 71.72 & 64.48 & 63.93 & \\
\hline L.S.D =0.05 & \multicolumn{3}{|c}{1.47} & \\
\hline
\end{tabular}

Table (4) showsthe effect of the sowing speed and the sowing depth and theiroverlaps on thefield efficiency. The table shows thatwhen the sowing speedincreasing from6.28 to 7.61 and then to $11.43 \mathrm{~km} /$ hthefield efficiencydecreased from 68.60 to 66.82 then to $64.71 \%$,respectively. The reason may be that increasing practical speed leads to reduce the 
time exploitation coefficient, the results agree withthose reached by Madlol (2010).As the table shows, when the sowing depth increased from 3 to $6 \mathrm{~cm}$,thefield efficiency decreased from 71.72 to $64.48 \%$.The reason, that increasingdepthleads toincreasethe deepening of the furrow openers which leads toincrease the slippage percentage and thus the practical front speed will decrease, which is one factors of field efficiency and thus the field efficiency is reduced.Theseresultsare consistent with the findings by Zedan (2006) and Madlol and Abdulrazzak (2012), while increasing the sowing depth from 6 to $9 \mathrm{~cm}$ did not have any significant effect on thefield efficiency.The interaction between the sowing speed and the sowing depth was significantin the field efficiency.Interaction of the sowing speed $6.28 \mathrm{~km} / \mathrm{hwith}$ the sowing depth $3 \mathrm{~cm}$ gave higher field efficiency amounting to $75.66 \%$, whilethe overlap of the sowing speed $11.43 \mathrm{~km} / \mathrm{hwith}$ the sowing depth $9 \mathrm{cmgave}$ lower field efficiency amounting to $61.68 \%$.

\section{- Fuel consumption}

Table (5):Effect of the sowing speed and depth on the fuel consumption

(L/ ha)

\begin{tabular}{|c|c|c|c|c|}
\hline \multirow{2}{*}{$\begin{array}{c}\text { The sowing speed } \\
(\mathrm{km} / \mathrm{h})\end{array}$} & \multicolumn{3}{|c|}{ The sowing depth(cm) } & $\begin{array}{c}\text { Average } \\
\text { sowing speed }\end{array}$ \\
\cline { 2 - 4 } & 3 & 6 & 9 & 19.17 \\
\hline 6.28 & 10.86 & 13.25 & 33.39 & 12.58 \\
\hline 7.61 & 7.96 & 10.00 & 19.77 & 8.11 \\
\hline 11.43 & 6.32 & 7.85 & 10.17 & 1.85 \\
\hline L.S.D =0.05 & \multicolumn{3}{|l}{6.48} & \\
\hline $\begin{array}{c}\text { Average sowing } \\
\text { depth }\end{array}$ & 8.38 & 10.37 & 21.11 & \\
\hline L.S.D =0.05 & \multicolumn{3}{|l}{1.85} & \\
\hline
\end{tabular}

Table (5) shows the effect of the sowing speed and the sowing depth andtheir overlaps on thefuel consumption. As seen from the table, when the sowing speedincreasedfrom 6.28 to 7.61 and then to $11.43 \mathrm{~km} / \mathrm{h}$, the amount of fuel consumption per unit area decreased from19.17 to 12.58 and then to $8.11 \mathrm{~L} / \mathrm{ha}$, respectively. The reason is that the tractor ability 
does not show optimally at slow velocities.Therefore,waste exists in energy.These results are consistent with the ones obtained byKassar (2011),as well as the high velocities need a short time period to complete unit area according to results of Al-Khafaji (2006) and Aday et al. (2008).Also the results in the same table show that increasing the sowing depth from 3 to 6 and then to $9 \mathrm{~cm}$ caused an increase in the fuel consumption from 8.38 to 10.37 and to $21.11 \mathrm{~L} /$ ha, respectively. The reason is that when increasing the sowing depth, furrow openers resistance will increase and that led to increased load on the tractor. These results are consistent with those obtained by Desbilles (2005) and Al-Aridhee (2011). The interaction between the sowing speed and the sowing depth was significantin the fuel consumption, whereas the dual overlapbetweenthe sowing speed $11.43 \mathrm{~km} / \mathrm{hwiththe}$ sowing depth $3 \mathrm{~cm}$ was superior in obtaining leastvalue of fuel consumption rate amounting to $6.32 \mathrm{~L} /$ ha. The highestvalue of fuel consumption rate was $33.39 \mathrm{~L} /$ ha resulting from overlap of the sowing speed $6.28 \mathrm{~km} / \mathrm{hwith}$ the sowing depth9cm.

\section{-Total operation costs}

The effect of the sowing speed and the sowing depth and their overlaps on the total operation costsfor machinery unit is tabulated in table ( 7 ). As seen from the table,increasingof the sowing speed from 6.28 to 7.61 and then to $11.43 \mathrm{~km} / \mathrm{h}$,the total operation costs decreasedfrom 26454 to 20393 then to 13594 ID / ha (ID=0.0008 US\$ orUS $\$=1250 I D$ ), respectively.The reason may be attributed to the fact that increasing of practical speed led to increase of practical productivity.Therefore the total costs decreased as a result of the reverse relationship between the productivity and total costs. These results are consistent with theresultsobtained by Al- Sharefy (2003). The same table shows that increasing of the sowing depth from 3 to 6 and then to 9 cmcaused an increase in total cost from 16721 to 19151 then to 24570 ID / ha.The reason is that the increase of the sowing depth has led to reduce the productivity and increased fuel consumption, therefore the total economic costs increased. These results are consistent with those obtained by Al-Janobi (2000) and Jabour (2010).The interaction between 
the sowing speed and the sowing depth was significantin the total operation costs.Interaction of the sowing speed $11.43 \mathrm{~km} \mathrm{/} \mathrm{hwiththe}$ sowing depth $3 \mathrm{~cm}$ was superior in obtaining lowest value of total operation costswhich amounted to 12022 ID / ha. Meanwhile,the highesttotal costs were 34338 ID / ha, which resulted from overlap of the sowing speed6.28km / hwiththe sowing depth9cm.

Table (6):Effect of the sowing speed and depth on the total operation $\operatorname{cost}(\mathrm{ID} * / \mathrm{ha})$

\begin{tabular}{|c|c|c|c|c|}
\hline \multirow{2}{*}{$\begin{array}{c}\text { The sowing speed } \\
(\mathrm{km} / \mathrm{h})\end{array}$} & \multicolumn{3}{|c|}{ The sowing depth $(\mathrm{cm})$} & \multirow{2}{*}{$\begin{array}{c}\text { Average sowing } \\
\text { speed }\end{array}$} \\
\cline { 2 - 4 } & 3 & 6 & 9 & 26454 \\
\hline 6.28 & 20701 & 24323 & 34338 & 20393 \\
\hline 7.61 & 17439 & 19433 & 24308 & 13594 \\
\hline 11.43 & 12022 & 13696 & 15063 & 974.16 \\
\hline L.S.D $=0.05$ & \multicolumn{3}{|c|}{3522.3} & \multirow{2}{*}{ *Iraqi Dinar } \\
\hline Average sowing depth & 16721 & 19151 & 24570 & \\
\hline L.S.D $=0.05$ & \multicolumn{3}{|c|}{974.16} \\
\hline
\end{tabular}

\section{-Energy requirements}

Table (7):Effect of the sowing speed and depth on energy requirements(kW.h / ha)

\begin{tabular}{|c|c|c|c|c|}
\hline \multirow{2}{*}{$\begin{array}{c}\text { The sowing speed } \\
(\mathrm{km} / \mathrm{h})\end{array}$} & \multicolumn{3}{|c|}{ The sowing depth $(\mathrm{cm})$} & $\begin{array}{c}\text { Average } \\
\text { sowing speed }\end{array}$ \\
\cline { 2 - 4 } & 3 & 6 & 9 & 69.18 \\
\hline 6.28 & 39.22 & 47.88 & 120.45 & 45.40 \\
\hline 7.61 & 28.76 & 36.06 & 71.38 & 29.40 \\
\hline 11.43 & 23.05 & 28.34 & 36.81 & 6.65 \\
\hline L.S.D =0.05 & \multicolumn{3}{|c}{23.42} & \\
\hline $\begin{array}{c}\text { Average sowing } \\
\text { depth }\end{array}$ & 30.34 & 37.43 & 76.21 & \\
\hline L.S.D =0.05 & \multicolumn{3}{|l}{6.65} & \\
\hline
\end{tabular}

Table (7) showsthe effect of the sowing speed and depth and their overlaps in theenergy requirements for machinery unit. The table shows that when the sowing speedincreased from6.28 to 7.61 and then to 
$11.43 \mathrm{~km} / \mathrm{h}$, theenergy requirementsdecreased from 69.18 to 45.40 then to $29.40 \mathrm{~kW}$. h /ha,respectively. The reason may be that increasing practical speed tends toreduce the required time to complete the sowing process and reducing the amount of fuel consumed. Thus power requirements for machinery unit decreased.As the table shows, when the sowing depth increased from 3 to 6 and then to $9 \mathrm{~cm}$, theenergy requirementshave increasedfrom 30.34 to 37.43 then to $76.21 \mathrm{~kW}$. h / ha.The reason is that increasingdepthleads toincrease the slippage percentage and thus thefuel consumption will increase.Sothe energy requirementsincreased.Theseresultsare consistent with the findings by Al-Sabbagh et al. (2012). The interaction between the sowing speed and the sowing depth was significantin the energy requirements.Interaction ofthe sowing speed $11.43 \mathrm{~km} /$ hwiththe sowing depth $3 \mathrm{cmgave}$ a lowest energy requirement which was $23.05 \mathrm{~kW}$. h / ha,whilethe overlap of the sowing speed $6.28 \mathrm{~km} / \mathrm{hwith}$ the sowing depth $9 \mathrm{cmgavethe}$ highest energy requirementsfor machinery unit which was $120.45 \mathrm{~kW} . \mathrm{h} / \mathrm{ha}$.

\section{CONCLUSION}

From the study conducted, the followings were concluded:

Increasing the sowing speedresulted in an increase in effective field capacity, percentage of slippage and a significant decrease in field efficiency, fuel consumption per unit area, total operation costs and energy requirements for machinery unit. Alsoincreasing the sowing depthresulted ina significant decreaseineffective field capacity,field efficiencyand a significant increase in thepercentage of slippage,fuel consumption per unit area, total operation costs and energy requirements for the machinery unit.The overlap betweenthe sowing speed and the sowing depthhas a very significant effect on all attributes which studied.

\section{RECOMMENDATIONS}

We recommend using the third speed of sowing $(11.43 \mathrm{~km} / \mathrm{h})$ with the first depth of sowing $(3 \mathrm{~cm})$, which gave a good technical, economic indicators and energy requirements for the machinery unit.We also recommend doing future studies similar to this research with planting different cerealcrops at several depthsof sowing, taking into account the 
grain drill field performance indicators and crop output in order to achieve the best combination between the machine and plant.

\section{REFERENCES}

Abdulrahman, R. A. 1992.Studying the effect of the sowing speed on some requirements of sowing by using grain drill "SZS - 2.1" with the tractor "Antar 71". M.Sc.Thes.,Fac. Agric., Baghdad Univ., Iraq. : 2 .

Abu Sabaa, A.; Karim.1980.Farm machinery.Dar Al-Maareffor Printing and Publishing. Egypt.

Aday, S. H.; S. I. Najm and M. S. Hmmood .2008. Fuel consumption per unit area and its relation with engine speed and forward speed for the tractor. J. Iraqi Agric., 8(1):168-180.

Ahmed, N. Y. N.; A. M.Munther .1987.Soil fertility and fertilizers. Trans. Ministry of Higher Edu.and Sci. Res.,Basrah Univ., Iraq. : 9.

Al-Aridhee, J. K. Z .2011. Effect of tractor's type, speed and tillage depth in some technical indicators of machine unit's and physical characteristics of the soil. M.Sc. Thes.,agric. Mach. and equip. Dep., Fac. Agric., Baghdad Univ., Iraq.: 32 - 34.

Al-Izzi, K. H. A. 2004.Effect of germination irrigation depth and sowing and tillage in wheat crop and its components under pivot sprinkler irrigation system. M.Sc. Thes., Soil and WaterDep., Fac. Agric., Baghdad Univ., Iraq.: 49.

Al-Janobi, A. A.; A. M. Zeinldin. 1997. Development of a soil bin test facility for soil tillage tool interaction studies. Fac. Agric., KingSaad Univ., Kingdom of Saudi Arabia, Agric., Res. Cen., No $72 .: 4$.

Al-Janobi, A.A., 2000. Data - acquisition system to monitor performance of fully mounted implement. J. Agric. Eng. Res.,Vol.75.: 167- 175. 
Al-Khafaji, A. J. J. 2006.Evaluation of the grain drill performance efficiency in two different soils. Ph.D. Thes.,Agric. Mech. Dep., Fac. Agric.,Baghdad Univ., Iraq.:115-159

Al-Mkhiol, F. F. M. 2005.The effect of the depths, sowing speeds and drill type in growing and wheat yield. M.Sc. Thes., Agric. Mech. Dep., Fac. Agric., Baghdad Univ., Iraq.:26.

Al-Rajabow, S. A. 2002.Studying the grain drill's performance indicators in the cultivation of barley crop. J. Iraqi Agric. 7 (6): 131- 136.

Al-Rawi,K.M.; M. K. Abdulaziz. 1980.Design and analysis of agricultural experiments,Directorate of Dar Al-Kotb for Printing and Publishing. Mosul Univ.,Ministry of Higher Ed.and Sci. Res.,Iraq.: 341.

Al-Sabbagh, A. A.; L. A. Z. Al-Hashemi and F. F. Al-Mkhiol 2012.Evaluate the performance efficiency of triple disc plow with New Holland tractor by using different disc tilt angles. Iraqi J. of Soil Sci.,12 (1): 105 - 115.

Al-Sharefy S. K. A.2003. A comparison between the effect of different tillage system in some soil physical properties and sunflower yields at the middle region of Iraq. M.Sc. Thes., Agric. Mech. Dep., Fac. Agric., Baghdad Univ.,Iraq.: 85 - 86.

Al-Sulaivany, A. M. S. 2005.Study the possibility of utilizing grain drill for sowing lentil crop in northern Iraq. M.Sc. Thes., Fac. Agric. and Forest. Mosul Univ., Iraq.: 30.

Al-Tahan, Y. H.; M. A. Hammeda and M. F. Abdelwahab.1991. Economic and management machinery and agricultural equipment. Ministry of Higher Ed. and Sci. Res., MosulUniv.,Iraq.: 378.

Anderson, W. K. and J. R. Garling. 2000. The Wheat Book - Principles and Practice. Agric. Western Australia Bul. 4443.: 39 - 52.

Awady, M. N.1987. Agricultural tractors. (In Arabic).Col. Agric., AinShams Univ.,Egypt.: 100. 
Awady, M. N. 2002.Engineering of agricultural machinery. (In Arabic).Col. Agric., Ain-Shams Univ.,Egypt.:154.

Awady, M. N.; M. M. Mubarak; A. M. Gindy and M. M. Hegazi. 2006. Introduction to agricultural engineering, Sowing machine section. (In Arabic). Col. Agric., Ain- Shams Univ.,Egypt. : 14-17.

A.S.A.E. standard .2000. Agricultural Machinery Management Data. ASAE D497.4,Am. Soc. of Agric. Eng., St. Joseph. MI 49085 9659. USA. : $350-357$.

Desbilles, J. 2005. Seedling system draft measurement. Agric. Mach. Res. and Design center.Univ. South Australia.

Elmo, R. 1981. Predicting machine field capacity for specific field and operation condition. Trans ASAE. : 79 - 1029.

Embaby, A. T. 1985. Acomparison of the different mechanization system for cereal crop production. M.Sc.Thes., Fac. Agric. Cairo Univ.,Egypt.:23

Glanze, P. 1972. Technical Fundamentals of Grain - maize -Mec. Prod. in the Tropical and Subtropical Regions. Ed.Leipzig. Translated. German Democ. Rep., Liz. Nr. 600 / 47 / $72 .: 9$-10.

Hanna, M.2002.Estimating the field capacity of farm machines. Iowa State Univ. Univ.Ext. File A3 - 24 April,: 4.

Hunt, D.R.2001. Cost determination in farm power and machinery management. $10^{\text {th }}$ ed. Iowa State Univ. press, Ames, Iowa.: 77 - 95.

Issct. 2004. Agricultural machinery costing methods and standard protocol. Agric. Eng. Sec.:1-12.

Jabour, H. A. 2010. Studyingof effect and interference soil moisture and plowing depth on the drag force resistance and total economic costs formachinery unit. Al-taqaniJ., 23 (2): 81 - 91.

Jadou, K.A.; A.Haider.2012. Effect of the sowing depth in properties of crop and components for six varieties of wheat. Iraqi J. Agric. Sci.,43 (1): 25-37. 
Jasim, A. A.; K. M. Madlol. 2011. Field performance of a tillage implement equipped with liquid fertilizer applicator. $1^{\text {st }}$ Nat. Agric. Cong. and Exposition on behalf of Ali NumanKirac with Inte. Participation. April 27-30, Eskisehir, Turkey .1(1): 1243 - 1255.

Kassar, F. H .2011. The effect of sowing speeds travelling gang angle of disc harrow range and tillage depth on some of the technical parameters for the machine unit and furrow dimensions. M.Sc. Thes., agric. Mach. and equip. Dep., Fac. of Agric., Baghdad Univ., Iraq.: 45 - 47.

Kepner, R.A.; R. Bainer and E.L.Barger. , 1982. Principles of farm machinery. $3^{\text {rd }}$ Ed., AVI pub.Co., USA. :26 - 31.

Khalilian, A.T.; H.Garner; H.L.Musen; R.B.Dodd and S.A.Hale.1988. Energy for conservation tillage in coastal. Plain soil. Trans. ASAE, 31 (5): 1333-1337.

Madlol, K. M.2010. Using locally assembled equipment to inject liquid fertilizer under soil surface. M.Sc. Thes.,Agric. Mach. and equip. Dep.,Fac. Agric., Baghdad Univ., Iraq.: 58.

Madlol, K. M.; A. J. Abdulrazak.2012. Measuring the field performance efficiency of liquid fertilizer inject equipment manufactured locally and the increase of element nutritious and bulk density for inject soil. Iraqi J. Soil Sci., 12 (1): 116 - 127.

Mohammed, M. A. 2005. Studying the possibility of utilizing some crop seeds drill in planting chickpeas. . M.Sc. Thes., Fac. Agric. and Forest. Mosul Univ., Iraq.: 42.

Zedan, B. A. 2006. Effect of some tillage systems, tillage depths and tractor speedson some performance parameters, soil physical properties and production of Indian pea crop (vigna radiate L.). M.Sc. Thes.,Agric. Mech. Dep.,Fac. Agric., Baghdad Univ.,Iraq.: 41. 


\section{الملخص العربي}

\section{تأثيرسُر عة وعمق البذارفي بعض المؤشر ات القنية والأقتصادية ومُنطلبات القدرة للوحدة المدوة الميراتية \\ قاسم موسى مدلول}

أجريت التجربة الحقلية في أحد حقول كلية الزر اعة - جامعة بغداد للعام 9 ه . . في تربة طينية غرينية وذلك لار اسة تأثثر سرع البذار في بعض مؤشر ات الأداء الفنية والأقتصادية ومتطلبات

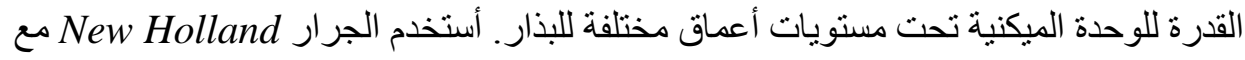

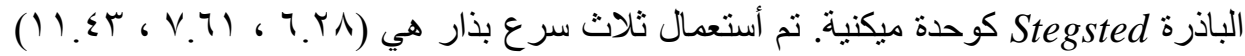

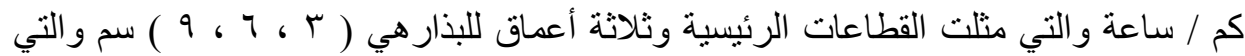

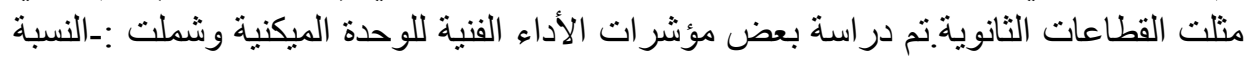
المئوية للأنز لاق،السعة الحقلية الفعلية،الكفاعة الحقلية وأستهلاك الوقود كما تم حساب تكاليف التشغيل الكلية ومتطلبات القدرة للوحدة الميكنية. نفذت التجربة بأستخدام تصميم الألواح المُّنشقة تحت نظام القطاعات العشوائية الكاملة وبثلاثة مُكررات. أظهرت النتائج تفوق سرعة الثة البذار الثالثة (Tء. (1) كم/ساعة على باقي السرع في تسجيلها لأعلى مُعدل للسعة الحقلية الفعلية

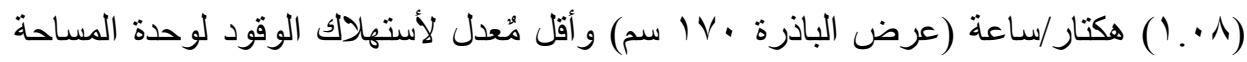

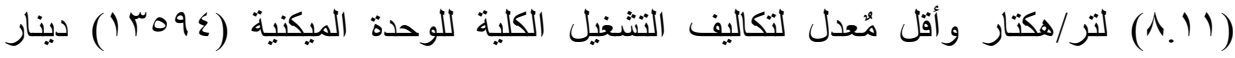
عر اقي/هكتار ( 10.875 دولار أمريكي/هكتار) مع أقل مُعدل لمُّنلبات القدرة للوحدة الميكنية

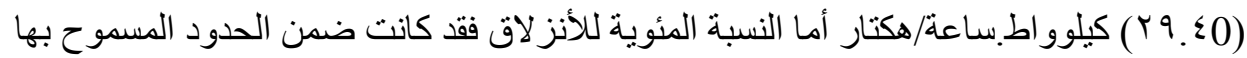

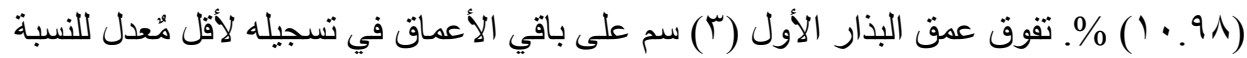

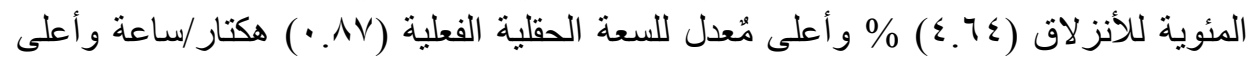

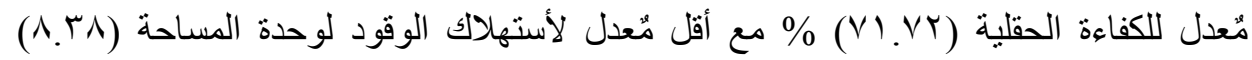

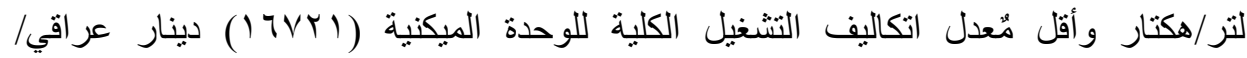
هكتار(13.376 دولار أمريكي / هكتار) مع أقل مُعدل لهُنطلبات القدرة للوحدة المدية الميكنية

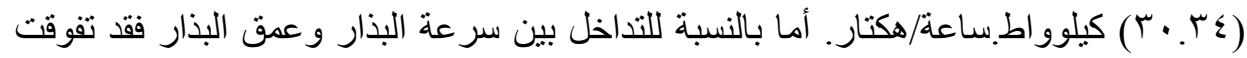

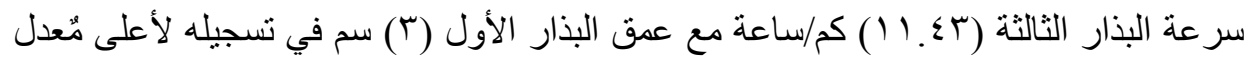

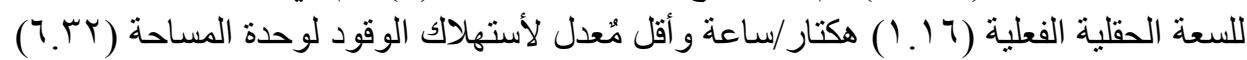

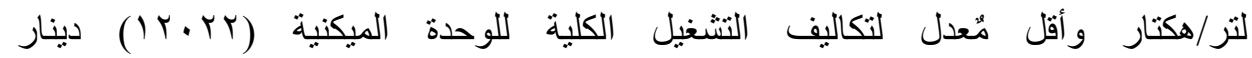
عر اقي/هكتار (T V V.9 دو لار أمريكي / هكتار) مع أقل مُعدل لمُتطلبات القدرة للوحدة الميكنية

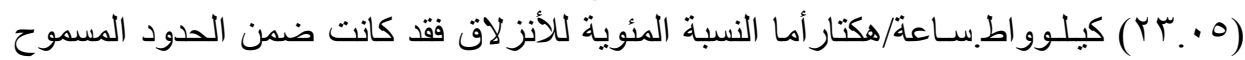
بها (7.09)

مُّدرس مُسـاعد - قسم المكائن والآلات الزراعية _ـ الزراعة - ج بغداد. 
في البدأ أقدم شكري وتقديري للسادة المحكمين لما ثبتوه من ملاحظات قيمة على بحثي هذا والتي

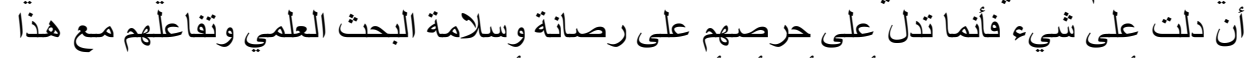

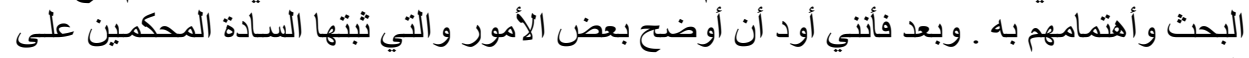

أن مقاسات خط كتابة البحث كانت ضمن توصبات المجلة مع وجود مسافات بين

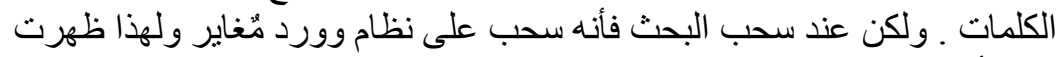
كل الأرقام باللغة الهندية وتداخلت الكلد الكمات فأنه

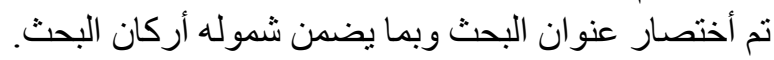

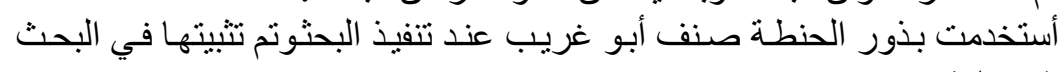
(ص ع $)$ سعة خزان البذور • 20 كيلو غر ام وتم تثبيته في البحث ( ص ع ع ).

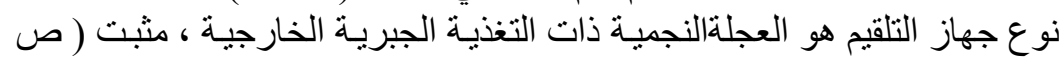
. (

العرض الثغال التصميمي للباذرة • V التم ،مثبت ( ص ع ) ).

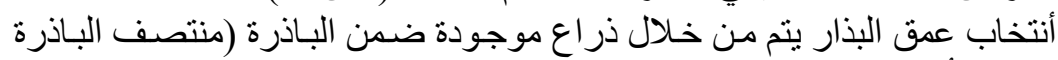

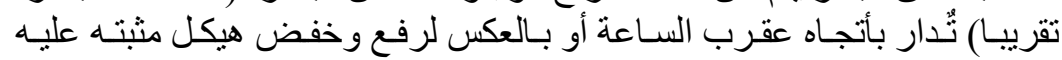

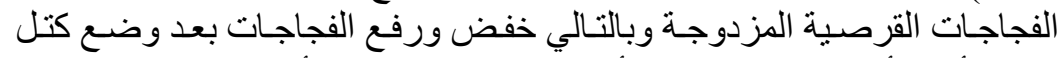

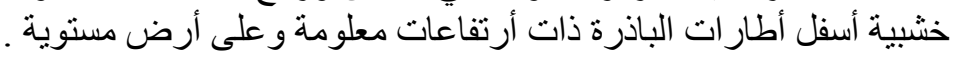

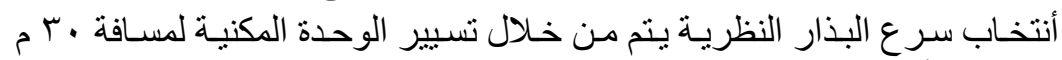

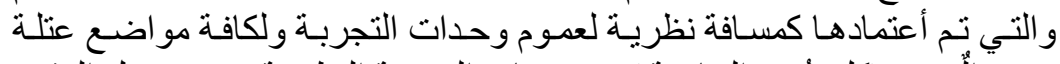

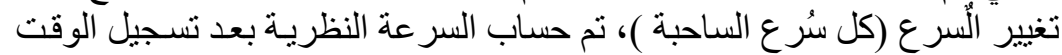

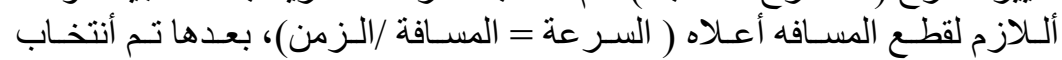

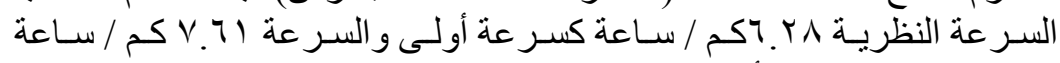

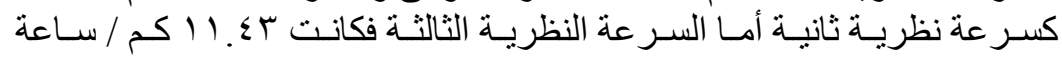

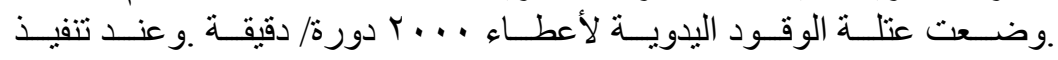

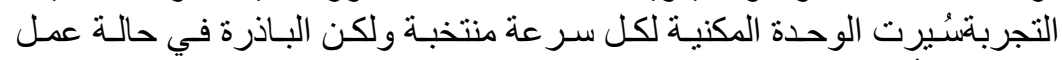

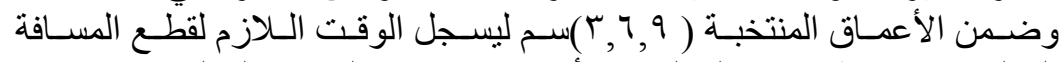

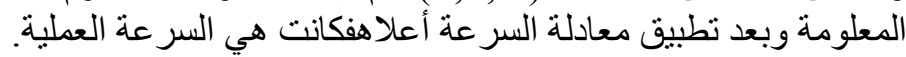

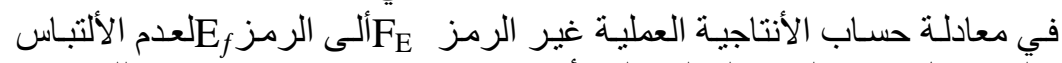

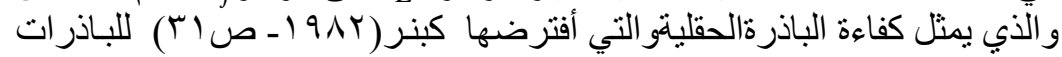

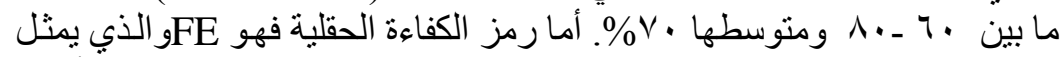
الكفاءة الحقلية الحقيقية التي تم الحصول عليها عند العمل بالباذرة كtegsted أثناء التجربة. تم تقريب الأرقام ألى مرتبتين بعد الفارزة لتتوحد كل أرقام الجداول ـلأنه في حالة

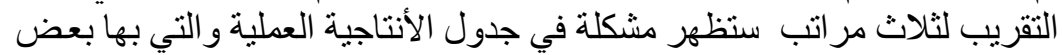

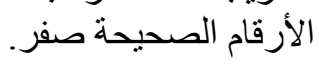

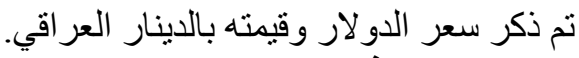
مع فائق شكري وتقديري للسادة المحكمين. 